Article

\title{
New Antimicrobial Bioactivity against Multidrug-Resistant Gram-Positive Bacteria of Kinase Inhibitor IMD0354
}

\author{
Iliana E Escobar ${ }^{1}$, Alexis White ${ }^{1}$, Wooseong Kim ${ }^{2, *}$ and Eleftherios Mylonakis ${ }^{1, *}$ \\ 1 Infectious Diseases Division, Department of Medicine, Warren Alpert Medical School of Brown University, \\ Rhode Island Hospital, Providence, RI 02903, USA; iliana_escobar@brown.edu (I.E.E.); \\ alexis_white@brown.edu (A.W.) \\ 2 College of Pharmacy, Graduate School of Pharmaceutical Sciences, Ewha Womans University, \\ Seoul 03760, Korea \\ * Correspondence: wooseong_kim@ewha.ac.kr (W.K.); emylonakis@lifespan.org (E.M.); Tel.: +1-401-444-7856 \\ (W.K.); +82-2-3277-3372 (E.M.)
}

Received: 31 August 2020; Accepted: 30 September 2020; Published: 1 October 2020

\begin{abstract}
Multidrug-resistant pathogens pose a serious threat to human health. For decades, the antibiotic vancomycin has been a potent option when treating Gram-positive multidrug-resistant infections. Nonetheless, in recent decades, we have begun to see an increase in vancomycin-resistant bacteria. Here, we show that the nuclear factor-kappa B (NF-kB) inhibitor $N$-[3,5-Bis(trifluoromethyl) phenyl]-5-chloro-2-hydroxybenzamide (IMD0354) was identified as a positive hit through a Caenorhabditis elegans-methicillin-resistant Staphylococcus aureus (MRSA) infection screen. IMD0354 was a potent bacteriostatic drug capable of working at a minimal inhibitory concentration (MIC) as low as $0.06 \mu \mathrm{g} / \mathrm{mL}$ against various vancomycin-resistant strains. Interestingly, IMD0354 showed no hemolytic activity at concentrations as high as $16 \mu \mathrm{g} / \mathrm{mL}$ and is minimally toxic to C. elegans in vivo with $90 \%$ survival up to $64 \mu \mathrm{g} / \mathrm{mL}$. In addition, we demonstrated that IMD0354's mechanism of action at high concentrations is membrane permeabilization. Lastly, we found that IMD0354 is able to inhibit vancomycin-resistant Staphylococcus aureus (VRSA) initial cell attachment and biofilm formation at sub-MIC levels and above. Our work highlights that the NF-KB inhibitor IMD0354 has promising potential as a lead compound and an antimicrobial therapeutic candidate capable of combating multidrug-resistant bacteria.
\end{abstract}

Keywords: high-throughput screening; vancomycin-resistant Staphylococcus aureus; vancomycin-resistant enterococci; IMD0354

\section{Introduction}

Methicillin-resistant Staphylococcus aureus (MRSA) is a Gram-positive pathogen that can cause skin abscess, bloodstream infections, and pneumonia [1,2]. Infections associated with MRSA are among the leading hospital-acquired infections [3] They are associated with high mortality and increased hospital stays that result in a higher cost burden [3].

Vancomycin is a glycopeptide able to inhibit cell wall synthesis by binding to the ends of D-Ala-D-Ala moieties of un-crosslinked Lipid II molecules [4]. Vancomycin is an antibiotic effective at treating Gram-positive multidrug-resistant pathogens, including MRSA [4,5]. However, strains such as vancomycin-intermediate Staphylococcus aureus (VISA, minimal inhibitory concentration $(\mathrm{MIC})=4-8 \mu \mathrm{g} / \mathrm{mL}$ ), vancomycin-resistant Staphylococcus aureus (VRSA, MIC $\geq 16 \mu \mathrm{g} / \mathrm{mL}$ ), as well as vancomycin-resistant enterococci (VRE) have emerged [5-9]. 
During normal cell wall synthesis, penicillin-binding proteins (PBPs) are able to attach to terminal D-Ala-D-Ala moieties of un-crosslinked Lipid II and link them. Vancomycin is able to bind them and thus block PBPs' attachment and crosslinking. This eventually leads to osmatic stress and bursting of the cell wall making vancomycin a potent bactericidal antibiotic [4].

Initially, it had been thought that resistance to vancomycin would be minimal given that it does not target enzymatic cell processes [4]. However, we now understand that vancomycin resistance is achieved by a group of genes encoding various enzymes and regulatory proteins that alter the original structure of Gram-positive bacterial walls $[4,10,11]$. These groups of genes are usually referred to as resistance cassettes. For vancomycin, the originally discovered cassette was named the "VanA"-type cassette which is composed of vanHAX cluster encoding enzymes and vanR and vanS genes that work as a two-component regulation system [12]. Numerous other resistance cassettes to vancomycin have been discovered and described, each of which includes VanA homologs [4]. These resistance cassettes encode genes that facilitate the conversion of D-Ala to D-Lac. In addition, other cassettes exist that help replace D-Ala with D-Ser [13].

Regardless of the change in the amino acid, the basic mechanism of resistance stays the same. By altering the original composition of Gram-positive Lipid II amino acid D-Ala-D-Ala vancomycin is no longer able to attach to the end of these glycopeptides and thus is unable to inhibit cell wall synthesis, creating bacteria mildly susceptible or resistant to vancomycin [4]. Given this threat, vancomycin resistance in Gram-positive bacteria poses a great risk to health care systems worldwide. As a last resort, antibiotics such as linezolid and daptomycin are clinically in use [14-16]. However, resistance to both drugs has become more prevalent throughout the decades $[14,17,18]$. Therefore, the development of new antibiotics to combat these drug-resistant bacteria is necessary and in dire need.

We screened $\sim 82,000$ small molecules to identify anti-infective agents that block Caenorhabditis elegans from a MRSA infection [19]. We identified several bioactive compounds, of which biological activities have been previously determined [20]. For example, the selective retinoic acid receptor $\gamma$ $(\mathrm{RAR} \gamma)$ agonist CD437 and CD1530 [19], the selective peroxisome proliferator-activated receptor $\gamma$ (PPAR $\gamma$ )-agonist nTZDpa [21], the anti-parasite drug bithionol [22], and insulin-like growth factor receptor inhibitor PQ401 [23]. Each show promising antimicrobial potency against multidrug-resistant Gram-positive pathogens and their persister cells. Considering that many hit compounds are excluded for further investigation due to their in vivo inactivity and toxicity, bioactive compound hits in particular have a high potential to become lead compounds because their in vivo efficacy and in vivo toxicity have been previously proven in several animal models [21-23]. Therefore, we further investigated other bioactive compound hits.

In this study, we explore another bioactive compound hit $N$-[3,5-Bis(trifluoromethyl)phenyl]5-chloro-2-hydroxybenzamide (IMD0354), previously described as an inhibitor of nuclear factor-kappa

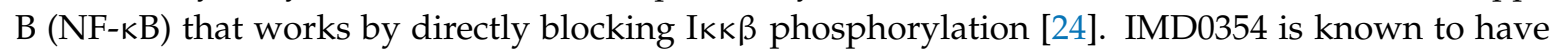
multiple biological activities. For instance, it has shown anti-cancer properties by directly inhibiting cell invasion and viability as well as acting as an adjuvant with other chemotherapy drugs without showing detectable toxicity [25-27]. In addition, it has also shown anti-inflammatory properties by blocking NF-кB and subsequent cytokine production [24,28]. Recently, it has been shown that IMD0354 potentiates colistin antimicrobial activity against colistin-resistant Acinetobacter baumannii [29]. However, the activity of this compound against Gram-positive bacteria and the activity of IMD0354 alone is not known to have antimicrobial potency. Here, we report, for the first time, that IMD0354 is notably potent against Gram-positive multidrug-resistant bacteria VRSA and VRE. We report that IMD0354 inhibits initial VRSA cell attachment and biofilm formation and is able to induce rapid membrane permeabilization at high concentrations of $\geq 4 \mu \mathrm{g} / \mathrm{mL}$. Furthermore, we demonstrate that IMD0354's antimicrobial activity is superior to its anti-cancer activity. 


\section{Results}

\subsection{IMD0354 Exhibits Anti-Staphylococcal Activity In Vitro \& in a Whole Animal C. elegans Infection Model}

We identified the NF-кB inhibitor IMD0354 (Figure 1a) as a hit compound that impedes C. elegans from an MSRA infection (Figure 1b). This compound completely protected all 15 C. elegans worms from the MRSA infection at $7.14 \mu \mathrm{g} / \mathrm{mL}$ (Figure 1b). Upon further evaluation, we determined the protection mechanism by which IMD0354 functioned was direct antimicrobial activity against MRSA MW2 with a MIC of $0.06 \mu \mathrm{g} / \mathrm{mL}$. Although IMD0354 has been known to have multiple bioactivities, such as anti-cancer, anti-inflammatory, and anti-viral activity [25-27], its direct antimicrobial activity has not been reported. Therefore, we focused on evaluating the potential of repurposing IMD0354 as an antimicrobial agent.

(a)<smiles>O=C(Nc1cc(C(F)(F)F)cc(C(F)(F)F)c1)c1cc(Cl)ccc1O</smiles>

(b)
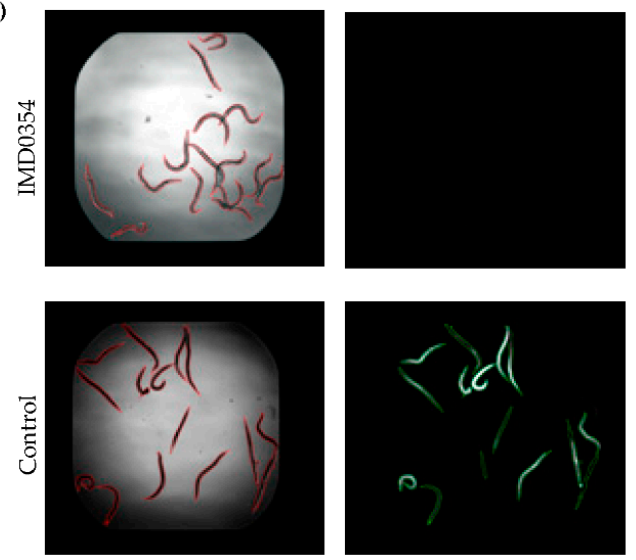

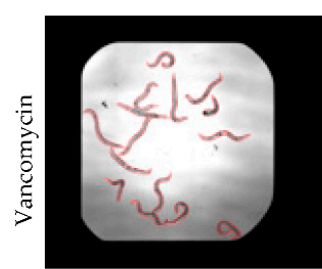

Brightfield

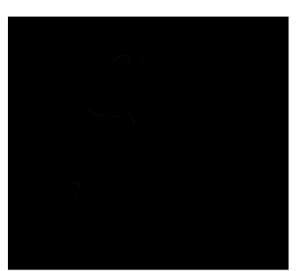

SYTOX

Figure 1. IMD0354 rescues C. elegans from MRSA infection. (a) Chemical structure of IMD0354. (b) Fifteen MRSA-infected C. elegans were treated with $7.14 \mu \mathrm{g} / \mathrm{mL}$ IMD0354, 0.1\% dymethlyl sulfoxide (DMSO) (control) and $10 \mu \mathrm{g} / \mathrm{mL}$ vancomycin for 5 days. After staining dead worms with SYTOX Orange, brightfield (left) and fluorescence (right) images were obtained.

\subsection{IMD0354 Shows Antimicrobial Activity against Multidrug-Resistant Gram-Positive Pathogens}

First, we tested the antimicrobial activity of IMD0354 against ESKAPE pathogens that often cause nosocomial infections and acquire antibiotic resistance [30,31]. ESKAPE pathogens consist of two Gram-positive bacteria, Enterococcus faecium and S. aureus, and four Gram-negative bacteria, Klebsiella pneumoniae, A. baumannii, Pseudomonas aeruginosa, and Enterobacter species [30,31]. IMD0354 displayed 
antimicrobial potency against E. faecium E004 with a MIC of $0.125 \mu \mathrm{g} / \mathrm{mL}$. In addition to S. aureus and E. faecium, IMD0354 exhibited significant antimicrobial activity against another Gram-positive bacterium, Enterococcus faecalis MMH 594, with a MIC of $0.25 \mu \mathrm{g} / \mathrm{mL}$. Next, we assessed its antimicrobial potency against the four Gram-negative pathogens. A previous study with IMD0354 against A. baumannii showed that IMD0354 can work as a potent adjuvant, enhancing the antimicrobial potency of colistin, while having no or minimal antimicrobial activity on its own [29]. In our hand, IMD0354 showed low antimicrobial activity against A. baumannii strain ATCC 17978 with MIC of $16 \mu \mathrm{g} / \mathrm{mL}$ (Table 1). However, it was not potent against P. aeruginosa PA14, K. pneumoniae WGLW2, and E. aerogenes EAE 2625 (Table 1). Taken together these findings suggest that IMD0354 is effective against Gram-positive bacteria, while, in the absence of another agent such as colistin, it demonstrates limited antimicrobial activity against Gram-negative bacteria.

Next, we assessed the antimicrobial potency of IMD0354 against a panel of vancomycin-intermediate or -resistant strains, including the vancomycin-resistant strain VRS1 [32], 14 VISA clinical isolates acquired from the center for disease control and prevention (CDC) [33], and five VRE strains [33-36]. We found that the MIC ranged from 0.06 to $0.25 \mu \mathrm{g} / \mathrm{mL}$ for all vancomycin-resistant and vancomycin-intermediate Staphylococcal isolates (Table 2) and $0.25 \mu \mathrm{g} / \mathrm{mL}$ for all VRE strains (Table 3). Considering that the MICs of last-resort antibiotics, such as daptomycin and linezolid, are 1-2 $\mu \mathrm{g} / \mathrm{mL}$ against VRSA and VRE [19,34], our results indicate that IMD0354 is a far more effective agent against these multidrug-resistant pathogens.

We then evaluated whether IMD0354 is bacteriostatic or bactericidal and found that IMD0354 is bacteriostatic to eight VISA strains (MBC/MIC ratio > 4) and bactericidal (MBC/MIC ratio $\leq 4$ ) to six VISA strains (Table 2). Additionally, IMD0354 is bacteriostatic to a VRSA strain, VRS1, and all VRE strains tested (Tables 2 and 3). These results were further confirmed by time-course killing kinetics of VRS1 cells treated with IMD0354 at $0.125 \mu \mathrm{g} / \mathrm{mL}(2 \times \mathrm{MIC}), 0.5 \mu \mathrm{g} / \mathrm{mL}(8 \times \mathrm{MIC}), 1 \mu \mathrm{g} / \mathrm{mL}(16 \times \mathrm{MIC})$, and $2 \mu \mathrm{g} / \mathrm{mL}$ (32× MIC) for up to $24 \mathrm{~h}$ (Figure 2). We found that IMD0354 was able to reduce colony forming units per $\mathrm{mL}(\mathrm{CFU} / \mathrm{mL})$ by approximately $1 \log$ in $24 \mathrm{~h}$ at a level of $8 \times$ to $16 \times$ MIC and up to $1.5 \log$ at $32 \times$ MIC (Figure 2). However, vancomycin alone did not inhibit the bacterial growth of VRS1 [32] even at high concentrations such as $512 \mu \mathrm{g} / \mathrm{mL}$ (Figure 2).

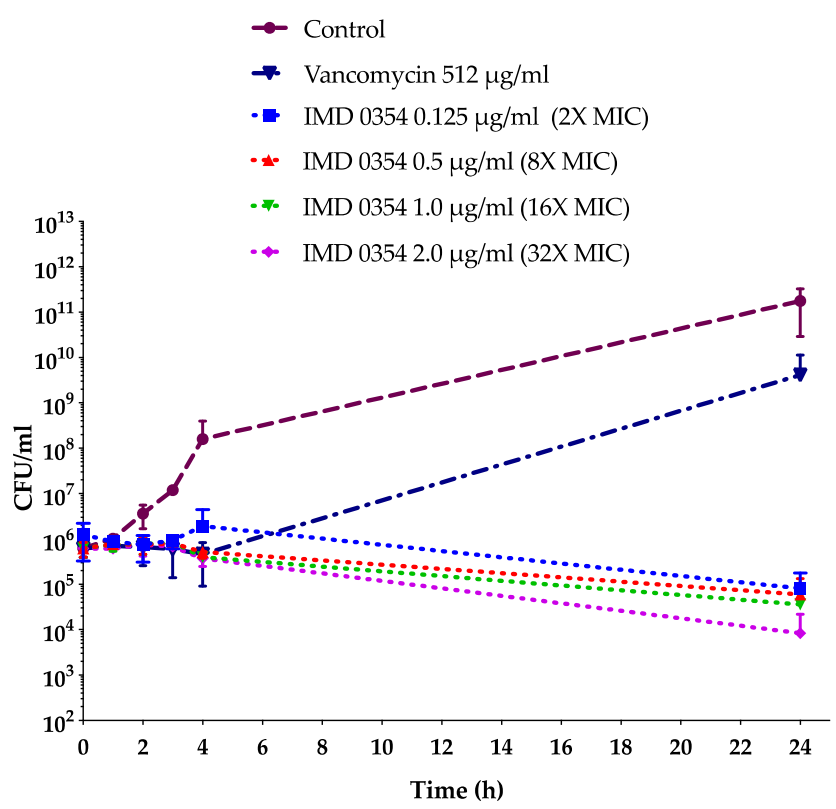

Figure 2. Time-killing curve shows IMD0354 is bacteriostatic against vancomycin-resistant strain VRS1. In total, $10^{6} \mathrm{CFU} / \mathrm{mL}$ of VRS1 overnight culture was treated with various concentrations of vancomycin and IMD0354. At times of 1, 2, 3, 4, and $24 \mathrm{~h}$, samples we collected, serially diluted, and spot-plated in order to enumerate CFU/mL. Each sample was tested in triplicate. ( $n=3, \pm$ S.D.). 
Table 1. Minimum inhibitory concentration $(\mu \mathrm{g} / \mathrm{mL})$ of IMD0354 to selected ESKAPE pathogens.

\begin{tabular}{cc}
\hline Strain & MIC \\
\hline Pseudomonas aeruginosa PA14 & $>64$ \\
Klebsiella pneumoniae WGLW2 & $>64$ \\
Acinetobacter baumannii ATCC 17978 & 16 \\
Enterobacter aerogenes EAE 2625 & $>64$ \\
Enterococcus faecalis MMH 594 & 0.25 \\
Enterococcus faecium E007 & 0.125 \\
\hline
\end{tabular}

Table 2. Minimum inhibitory concentration $(\mu \mathrm{g} / \mathrm{mL})$ of NF- $\mathrm{kB}$ inhibitors IMD0354 against vancomycin-resistant Staphylococcus aureus (VRSA) and vancomycin-intermediate Staphylococcus aureus (VISA) clinical strains.

\begin{tabular}{ccccc}
\hline & \multicolumn{2}{c}{ IMD0354 } & \multicolumn{2}{c}{ Vancomycin } \\
\cline { 2 - 5 } Strain & MIC & MBC & MIC & MBC \\
\hline VRS1 & 0.06 & 2 & $>64$ & $>64$ \\
VISA 215 & 0.25 & 0.5 & 8 & 8 \\
VISA 216 & 0.06 & 2 & 8 & 16 \\
VISA 217 & 0.125 & 0.5 & 8 & 8 \\
VISA 218 & 0.06 & 0.5 & 8 & 8 \\
VISA 219 & 0.06 & 1 & 8 & 16 \\
VISA 220 & 0.25 & 2.0 & 8 & 16 \\
VISA 221 & 0.06 & 1.0 & 8 & 8 \\
VISA 222 & 0.125 & 2.0 & 8 & 8 \\
VISA 223 & 0.125 & 1.0 & 4 & 8 \\
VISA 224 & 0.25 & 2 & 4 & 16 \\
VISA 225 & 0.125 & 0.25 & 4 & 8 \\
VISA 226 & 0.06 & 0.125 & 4 & 4 \\
VISA 227 & 0.25 & 0.5 & 8 & 8 \\
VISA 228 & 0.125 & 0.5 & 4 & 8 \\
\hline
\end{tabular}

Table 3. Minimum inhibitory concentration $(\mu \mathrm{g} / \mathrm{mL})$ of NF- $\mathrm{kB}$ inhibitors IMD0354 against vancomycin-resistant enterococci (VRE) clinical strains.

\begin{tabular}{ccccc}
\hline & \multicolumn{2}{c}{ IMD0354 } & \multicolumn{2}{c}{ Vancomycin } \\
\cline { 2 - 5 } Strain & MIC & MBC & MIC & MBC \\
\hline EM C68 [35] & 0.25 & 8 & 64 & $>64$ \\
EM D366 [36] & 0.25 & 8 & 64 & $>64$ \\
EM WB312 [37] & 0.25 & 8 & 64 & $>64$ \\
EM WC176 [37] & 0.25 & 8 & 64 & $>64$ \\
EL V583 [38] & 0.25 & 8 & 64 & $>64$ \\
\hline
\end{tabular}

EM: Enterococcus faecium, EL: Enterococcus faecalis.

\subsection{Cytotoxicity of IMD0354 on Human Cells and C. elegans}

IMD0354 has been used in in vitro and in vivo studies as a potent NF- $\mathrm{kB}$ inhibitor and potential anti-cancer agent both dependent and independent of NF- $\mathrm{kB}$ inhibition [24-27]. We assessed the inhibitory activity of IMD0354 against the human liver hepatocellular carcinoma cell line (HepG2) and human kidney proximal tubular cell line (HKC-8) [39]. Consistent with previous studies, our results showed that IMD0354 has a median lethal concentration $\left(\mathrm{LC}_{50}\right)$ of $1.1 \mu \mathrm{g} / \mathrm{mL}$ and $0.94 \mu \mathrm{g} / \mathrm{mL}$, respectively. Noteworthy, IMD0354's $\mathrm{LC}_{50}$ against cancer cells is approximately 16 times higher than its MIC to VRS1 (Figure 3). Additionally, it has been reported that IMD0354 does not induce detectable toxicity while showing significant efficacy in murine cancer models at concentrations as high as $30 \mathrm{mg} / \mathrm{kg}$ [26]. Consistently, IMD0354 was not toxic to C. elegans up to $2 \mu \mathrm{g} / \mathrm{mL}$ and showed $90 \%$ survival up to $64 \mu \mathrm{g} / \mathrm{mL}$ (Figure 4). Lastly, IMD0354 did not cause human red blood cell hemolysis 
up to $16 \mu \mathrm{g} / \mathrm{mL}$ (Figure 5). These results indicate that IMD0534 has a higher therapeutic index when used as antimicrobial compared to toxicity.

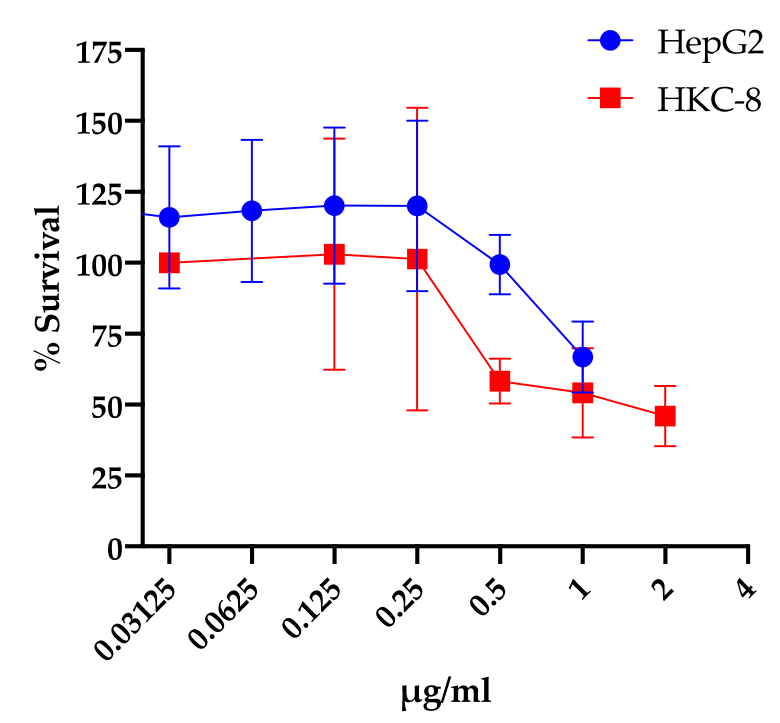

Figure 3. Dose toxicity studies show IMD0354 has cytotoxicity activity above MIC levels. Cytotoxicity testing of human liver cell line HepG2 and human kidney proximal tubular cell line HKC-8 at various concentrations of IMD0354. $\mathrm{LC}_{50}$ of IMD0354 is $1.1 \mu \mathrm{g} / \mathrm{mL}$ and is $0.94 \mu \mathrm{g} / \mathrm{mL}$, respectively. Each sample was tested in triplicate. $(n=3, \pm$ S.D.).

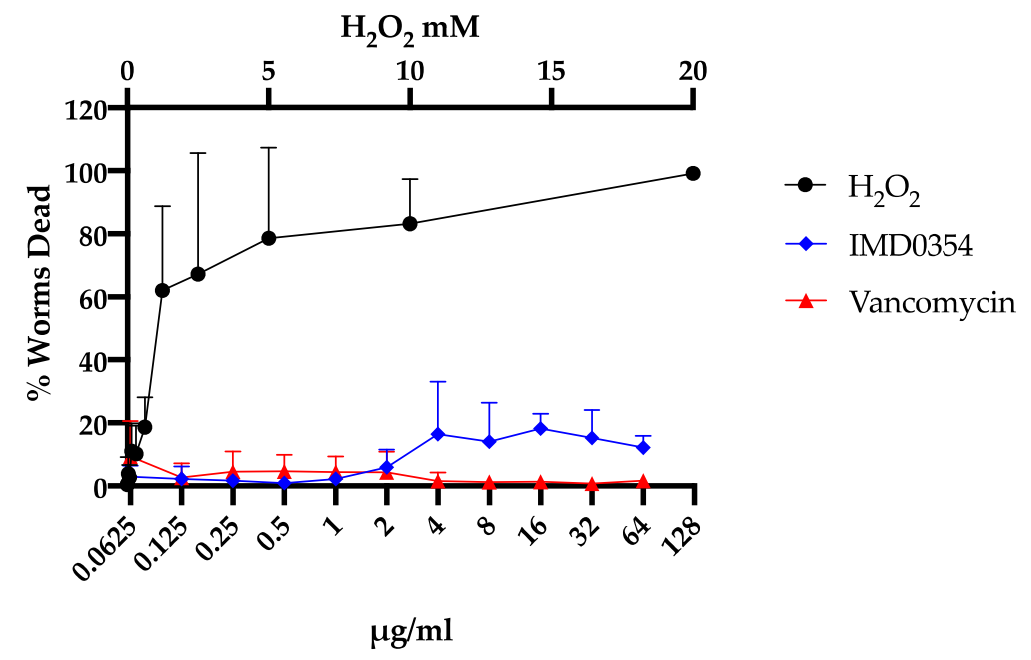

Figure 4. IMD0354 shows minimal toxicity toward C. elegans. Survival of C. elegans treated with various concentrations of IMD0354, normalized to C. elegans treated with DMSO. $\mathrm{H}_{2} \mathrm{O}_{2}$ was used as positive control. ( $n=3, \pm$ S.D). Bottom error bars are omitted for clarity. 


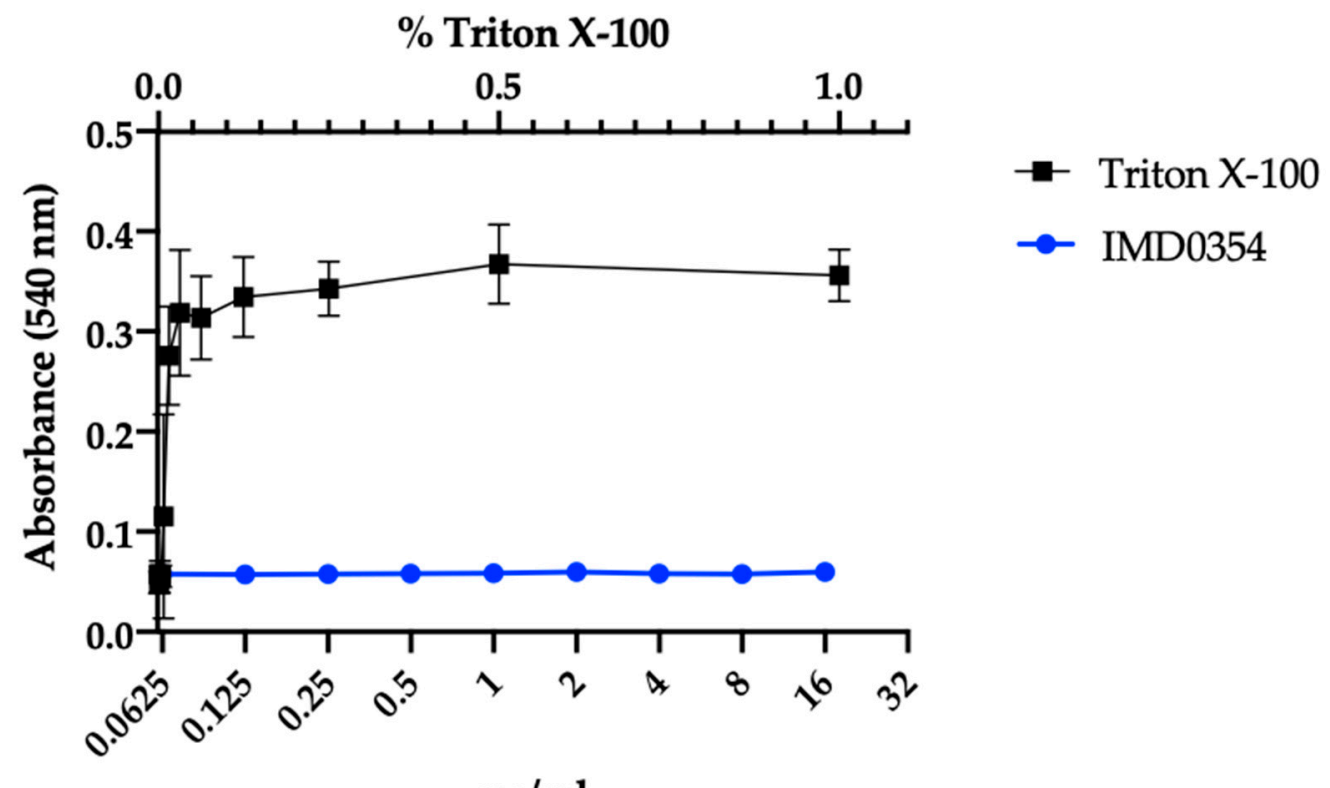

\section{$\mu \mathrm{g} / \mathrm{ml}$}

Figure 5. IMD0354 does not show hemolytic activity. Human red blood cells were incubated with serially diluted IMD0354 $(0.0156-16 \mu \mathrm{g} / \mathrm{mL})$ and normalized to hemolysis of $1 \%$ Triton-X 100. Each sample was tested in triplicate $(n=3, \pm$ S.D).

\subsection{IMD0354 Shows Bacterial Membrane Permeability at High Concentrations}

Next, we tested whether IMD0534 affects bacterial membrane permeability using a membrane-impermeable DNA binding dye, SYTOX Green [40]. IMD0354 was not able to induce an increase in fluorescence up to $2 \mu \mathrm{g} / \mathrm{mL}$. However, the VRS1 cells treated with equal or more than $4 \mu \mathrm{g} / \mathrm{mL}$ IMD0354 exhibited a rapid increase in SYTOX Green fluorescence, indicating that IMD0354 is able to permeabilize VRS1 membrane at high concentration $(\geq 4 \mu \mathrm{g} / \mathrm{mL})$. Together with the time-killing data (Figure 2), we conclude that, at high concentrations, IMD0354 kills bacteria by disrupting the bacterial membrane integrity (Figure 6). In contrast, at low concentrations, IMD0354 inhibits VRS1 growth rather than killing VRS1 and does not induce detectable membrane permeabilization. These results demonstrate that IMD0354 may have multiple antimicrobial mechanisms of action, possibly dependent on its concentration levels. 


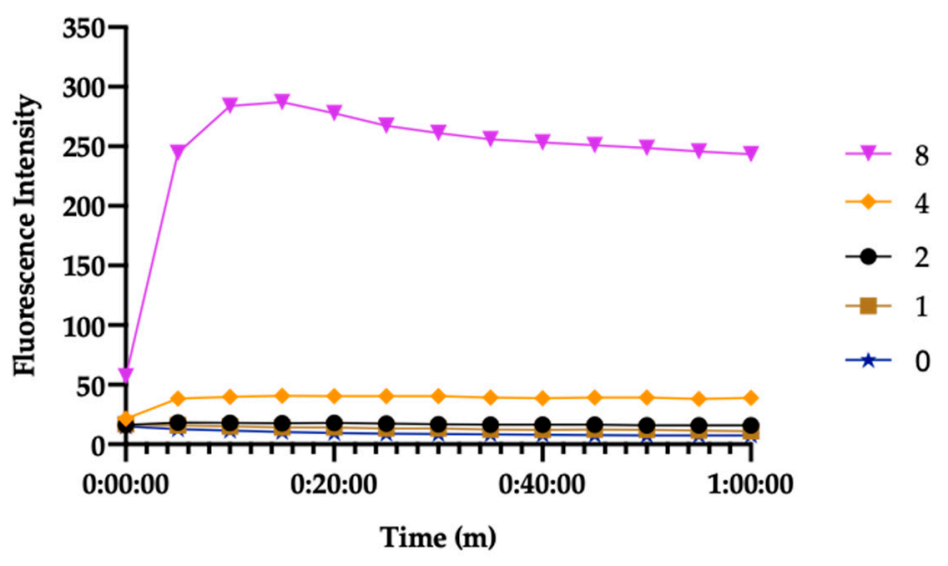

Figure 6. IMD0354 induces membrane permeabilization at high concentrations. VRS1 membrane permeabilization was measured spectrophotometrically by monitoring the uptake of SYTOX Green (excitation wavelength of $485 \mathrm{~nm}$ and an emission wavelength of $525 \mathrm{~nm}$ ) during treatment with IMD0354 at various concentrations. The legend units are $\mu \mathrm{g} / \mathrm{mL}$. Each assay was tested in triplicate. $(n=3, \pm$ S.D). Error bars are omitted for clarity.

\subsection{IMD0354 Inhibits Initial Cell Attachment in a Dose-Dependent Manner and Fully Inhibtis Biofilm Formation}

Biofilms are resistant to antibiotic treatment and are responsible for various chronic and recalcitrant infections [41]. Cell attachment is the initial stage of biofilm formation and development and is the main target in one of the principle strategies of biofilm management [42,43]. Therefore, it is clinically relevant to identify agents that inhibit biofilms during this critical step of initiation. Currently, there are already methods used to inhibit initial biofilm formation such as host-derived glycoproteinaceous film coating of medical implants and devices [44]. Likewise, molecular compounds such as aryl rhodanines or calcium chelators have also shown some success at inhibiting biofilm initial cell attachment [43]. To test the inhibitory activity of IMD0354 on biofilm initial cell attachment, we incubated a high density of VRSA strain VRS1 bacterial culture $\left(\sim 8 \times 10^{7} \mathrm{CFU} / \mathrm{mL}\right)$ with various concentrations of IMD0354 (Figure 7) for $1 \mathrm{~h}$ and measured cell attachment using XTT (2-3-bis(2-methyloxy-4-nitro-5sulfophenyl)-2H-tertazolium-5-carboxanilide) fluorescent dye. We found that IMD0354 is indeed able to block biofilm initial cell attachment in a dose-dependent manner with a greater than $60 \%$ inhibition at $4 \times \mathrm{MIC}\left(0.25 \mu \mathrm{g} / \mathrm{mL},{ }^{*} p=0.0059\right)$ (Figure $\left.7 \mathrm{a}\right)$. Furthermore, we argue that the reduction in initial cell attachment is not due to antimicrobial activity given that we show that IMD0354 does not reduce cell viability after $1 \mathrm{~h}$ of incubation (Figure 2). To support these findings, we tested whether IMD0354 inhibits mature biofilm formation at concentrations which showed reduced initial cell attachment. As expected, we found that IMD0354 can completely inhibit biofilm formation beginning at a MIC concentration of $0.06 \mu \mathrm{g} / \mathrm{mL}\left({ }^{*} p=0.0005\right)$ with $>50 \%$ inhibition at a sub-MIC concentration of $0.0313 \mu \mathrm{g} / \mathrm{mL}\left({ }^{*} p=0.0077\right)$. However, given that we showed that IMD0354 was unable to fully inhibit biofilm initial cell attachment but was still able to disrupt biofilm formation, we speculate that the inhibition of initial cell attachment is not the sole mechanism by which IMD0354 can hinder biofilm formation. Our working hypothesis is that the effect IMD0354 has on biofilm formation is due to the combined activity the compound has on bacterial growth and its ability to impede initial cell attachment. Furthermore, IMD0354 is unable to eradicate fully mature biofilm once established (data not shown). 
(a)

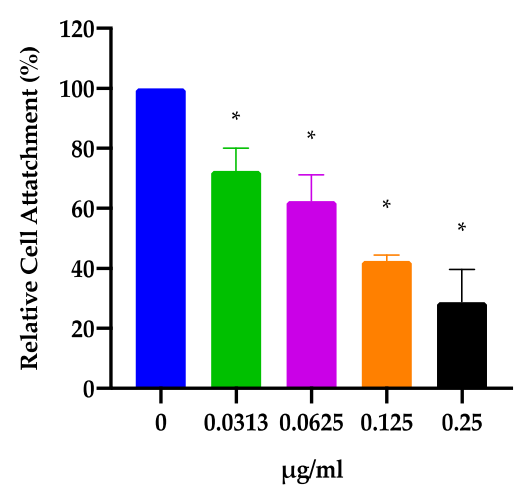

(b)

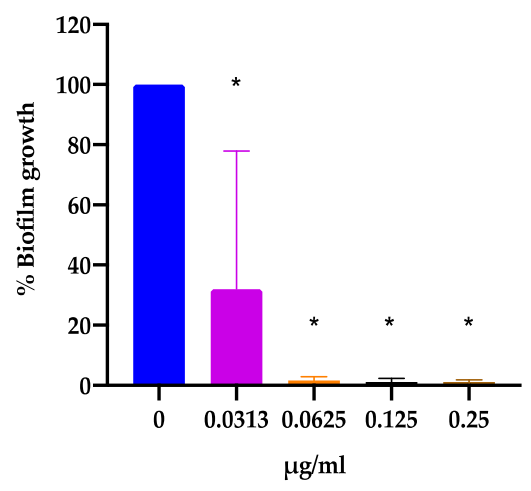

Figure 7. IMD0354 shows dose-dependent inhibition of initial cell attachment and complete inhibition of biofilm formation. (a) VRS1 cells were incubated in Brain Heart Infusion broth (BHI) $0.5 \%$ glucose at an optical density at $600 \mathrm{~nm}\left(\mathrm{OD}_{600}\right)$ of 1.0 for $1 \mathrm{~h}$. Cells were washed three times with phosphate buffered saline (PBS) and then treated with XTT to measure cell attachment. Measurements were normalized to a non-treatment control $(0 \mu \mathrm{g} / \mathrm{mL})$. (b) VRS1 cells were incubated in BHI $0.5 \%$ glucose at an $\mathrm{OD}_{600}$ of 0.05 and indicated concentrations of IMD0354 for $24 \mathrm{~h}$. At $24 \mathrm{~h}$ biofilm were washed 3 times with PBS. Total biofilm mass was measured using $1 \%$ crystal violet $(n=3, \pm$ S.D.).

\subsection{IMD0354 Does Not Affect the Viability of Antibiotic-Tolerant Cells nor Synergize with Conventional Antibiotics}

Membrane-active antimicrobial agents tend to show antimicrobial potency against non-growing dormant antibiotic-tolerant bacteria and synergism with other antibiotics [45]. Thus, we assessed if IMD0354 is potent against the antibiotic-tolerant S. aureus VRS1 and acts synergistically with conventional antibiotics. In this series of experiments, we isolated antibiotic-tolerant cells as previously described [46] and treated them with various concentrations of IMD0354 for $4 \mathrm{~h}$. IMD0354 was not able to kill antibiotic-tolerant cells even at high concentrations such as $4 \mu \mathrm{g} / \mathrm{mL}(64 \times$ MIC) (Supplementary Figure S1). Next, we determined whether IMD0354 worked synergistically with other antibiotics against $S$. aureus VRS1. We performed various checkerboard assays, testing vancomycin, gentamicin, ciprofloxacin, and daptomycin in conjunction with IMD0354. Unlike in the case of Gram-negative bacteria [29], we did not find any synergy or antagonism between any antibiotics tested, only additive or indifference effects (data not shown).

\section{Discussion}

Here, we report the novel finding that the kinase inhibitor IMD0354 is able to prolong the life of C. elegans during a lethal MRSA infection [19]. We show that IMD0354 inhibits MRSA growth at MIC levels as low as $0.06 \mu \mathrm{g} / \mathrm{mL}$ and can inhibit growth of other multidrug-resistant Gram-positive bacteria including VRSA, VISA, and VRE. At high concentrations, IMD0354 permeabilizes Gram-positive bacterial membranes at concentrations $\geq 4 \mu \mathrm{g} / \mathrm{mL}$ (Figure 6).

In the previous report by Barker et al., IMD0354 was found to have no antimicrobial activity on its own against Gram-negative bacteria, which is consistent with our antimicrobial susceptibility test on Gram-negative ESKAPE pathogens (Table 1). Barker et al. demonstrated that the enhanced potency of colistin by IMD0354 results from its ability to reverse the colistin-resistance modification of lipid A of colistin-resistant bacteria [29]. Nonetheless, at this time, we cannot find any parallels between the Gram-negative mode of action of IMD0354 given that Gram-positive bacteria do not produce lipid A [47]. This may explain why we did not find any synergistic effect even with cell wall- or cell membrane-targeting antimicrobial agents, such as vancomycin or daptomycin, against Gram-positive VRS1. 
In addition, IMD0354 inhibited the initial cell attachment for biofilm formation in a dose-dependent manner and completely inhibited biofilm formation at sub-MIC levels and above (Figure 7). It is possible that this phenotype is partially dependent on the antimicrobial activity of IMD0354. However, we find this unlikely given our experimental design and supporting data. For example, based on our killing kinetics assay, we show that IMD0354 has no antibacterial effect at $1 \mathrm{~h}$ post drug incubation. In addition, initial cell attachment assays are run using $10^{2}$ more bacteria than our killing kinetics studies. Therefore, we conclude that the reduction in initial cell attachment is independent of the antimicrobial activity by IMD0354. Biofilms are a significant threat given their high resistance to antibiotic therapy and common target of medical devices [41,42]. Biofilm formation and development consists of five stages, the first being cell attachment [42]. Attachment is controlled via various cell wall-anchoring proteins, including microbial surface components recognizing adhesive matrix molecules (MSCRAMMs) [42]. Our working hypothesis is that IMD0354 targets these associated genes or proteins and thus results in a decrease in biofilm attachment.

Furthermore, we also found that IMD0354 is a more potent antimicrobial than a cell toxicity agent. Previous studies have shown that IMD0354 exhibits anti-cancer activity by inhibiting cell invasion, viability, as well as acting as an adjuvant with other chemotherapy drugs [25-27]. In particular, our studies show that the average $\mathrm{LC}_{50}$ of IMD0354 toward two cancerous cell lines is $1.04 \mu \mathrm{g} / \mathrm{mL}$, approximately $17 \times$ greater than its MIC of $0.06 \mu \mathrm{g} / \mathrm{mL}$. IMD0354 is known to selectively suppress the proliferation of cancerous cells over normal cells [48]. For instance, unlike on neoplastic mast cells, it did not affect the proliferation of normal human mast cells at $1 \mu \mathrm{M}(0.4 \mu \mathrm{g} / \mathrm{mL})$ [48]. Furthermore, various groups have used IMD0354 in murine in vivo models from $1 \mathrm{mg} / \mathrm{kg}$ up to $30 \mathrm{mg} / \mathrm{kg}$ over several weeks and have reported no detectable toxicity $[24,26]$. These previous in vitro and in vivo results demonstrate that IMD0354 is relatively non-toxic to normal cells. Consistently, we observed the cytotoxic effect of IMD0354 on cancerous cells at $1 \mu \mathrm{g} / \mathrm{mL}$ (Figure 3), while it did not cause cytotoxicity to the model animal C. elegans at $\sim 7 \mu \mathrm{g} / \mathrm{mL}$ (Figure 1b). It is worth noting the MIC of IMD0354 against the VRSA strain VRS1 is $0.06 \mu \mathrm{g} / \mathrm{mL}$ (Table 2), which is about one order of magnitude lower than its effective concentration on cancer cell lines. Given these findings, we propose that IMD0354 has greater promise in terms of being repurposed as an antimicrobial rather than an anti-cancer agent.

The antibacterial activity of other anti-cancer drugs, such as mitomycin $\mathrm{C}$ and cisplatin, has been validated and these drugs have been proposed as antimicrobial candidates against multidrug-resistant bacteria $[49,50]$. For instance, mitomycin C demonstrates an $\mathrm{LC}_{50}$ of $27 \mu \mathrm{M}(9.03 \mu \mathrm{g} / \mathrm{mL})$ against HepG2 cancer cells and a MIC ranging between $0.2-15 \mu \mathrm{g} / \mathrm{mL}$ to multiple Gram-negative and Gram-positive bacteria [49]. Alternatively, cisplatin shows an $\mathrm{IC}_{50}$ of $2 \mu \mathrm{g} / \mathrm{mL}$ against HepG2 cancer cells and a MIC $>50 \mu \mathrm{g} / \mathrm{mL}$ for both Gram-positive and Gram-negative bacteria [50,51]. Nonetheless, low-dose administration of cisplatin to septic mice improves their bacterial clearance [52]. From these studies, we find that certain anti-cancer agents might have antimicrobial activity at concentrations similar to or greater than their anti-cancer activity. In contrast, IMD0354 has an $\mathrm{LC}_{50}$ of $1.1 \mu \mathrm{g} / \mathrm{mL}$ to HepG2 cells and a MIC of $0.06 \mu \mathrm{g} / \mathrm{mL}$. These data demonstrate that IMD0354 has a greater antimicrobial to anti-cancer activity ratio than both mitomycin $\mathrm{C}$ and cisplatin.

Interestingly, the antimicrobial and anti-cancer mechanism of action (MOA) of mitomycin $\mathrm{C}$ and cisplatin appear to be similar as they both cross-link mammalian and bacterial cell DNA, thus leading to cell death $[49,50]$. On the other hand, the anti-cancer MOA of IMD0354 has been shown to be both NF- $\kappa B$ dependent and independent [24-27]. Given that bacteria have no NF- $\kappa B$ it is reasonable to assume that the antibacterial MOA of IMD0354 is different from its anti-cancer activity. Importantly, this information allows us to speculate that IMD0354 could be a promising lead compound that can be structurally optimized to abate or nullify anti-cancer activity while retaining its antimicrobial properties.

In addition to anti-cancer activity, IMD0354 has other bioactivities. Onai et al. and Sugita et al. used IMD0354 to directly inhibit NF-KB and subsequently target inflammation [24,28]. From these in vitro studies, we glean that IMD0354 can significantly inhibit cytokine production at $1 \mu \mathrm{M}(0.4 \mu \mathrm{g} / \mathrm{mL})$ [24], nearly six times more than IMD0354's MIC $(0.06 \mu \mathrm{g} / \mathrm{mL})$. Furthermore, in vivo data from Onai et al. 
showed a significant reduction in inflammation in a rat myocardial ischemia/reperfusion injury model after treatment with IMD0354. In these studies rats, were treated with either $1 \mathrm{mg} / \mathrm{kg}, 5 \mathrm{mg} / \mathrm{kg}$, or $10 \mathrm{mg} / \mathrm{kg}$ of IMD0354 over 4 weeks. After treatment, it was found that only $5 \mathrm{mg} / \mathrm{kg}$ and $10 \mathrm{mg} / \mathrm{kg}$ had significant differences in reducing infarction size. We therefore suggest that there is a low concentration window in which even IMD0354 can be administered as an antibiotic with low cross-activation of other bioactivities.

Overall, the continued evolution of antibiotic resistance to last-resort therapeutics such as vancomycin persist as a primary threat. The C. elegans-MRSA high-throughput screening (HTS) system has become an invaluable tool in drug discovery research as this model is unique in its ability to find antimicrobial kinase inhibitors that would otherwise be neglected due to their toxicity, such as NF- $\kappa B$ inhibitors. Moving forward, we find it important to distinguish the structural relationship between NF- $\mathrm{B}$ inhibition and antimicrobial effect. Further research into analogs would be beneficial in advancing our understanding of the mechanism of action of kinase inhibitors, which can illuminate new antimicrobial targets against multidrug-resistant bacteria. In additional, experiments testing the efficacy of IMD0354 as an antimicrobial in a murine in vivo model would be insightful. Given IMD0354's low MIC, we speculate that there may be a tritiated dose that does not induce significant NF- $\mathrm{B}$ inhibition but is still able to inhibit bacterial growth. However, at this time, these experiments fall outside the focus of our study.

\section{Materials and Methods}

\subsection{Bacterial Strains and Growth Conditions}

All strains used for these studies are listed in Table 4. All VISA and VRSA strains were grown overnight in trypsin soy broth (TSB) at $37^{\circ} \mathrm{C}$, followed by shaking at 180-225rpm. All Enterococcal strains were grown overnight in Brain Heart Infusion broth (BHI) at $37^{\circ} \mathrm{C}$, followed by shaking at 180-225 rpm.

Table 4. Bacterial strains used in this study.

\begin{tabular}{ll}
\hline Bacterial Name & Strain \\
\hline vancomycin-intermediate Staphylococcus aureus & VRS1 [32] \\
vancomycin-intermediate Staphylococcus aureus & VISA 215, 216, 217, 218, 219, 220, 221, 222, 223, 224, \\
(clinical isolates) & $225,226,227,228$ \\
vancomycin-resistant Enterococcus faecium (clinical isolates) & C68 [35], D366 [36], WB312 [37], WC176 [37] \\
vancomycin-resistant Enterococcus faecalis (clinical isolate) & V583 [38] \\
methicillin-resistant Staphylococcus aureus & MW2 \\
Klebsiella pneumoniae & WGLW2 \\
Acinetobacter baumannii & ATCC 17978 \\
Enterococcus faecalis & MMH 594 \\
Enterococcus faecium & E007 \\
Pseudomonas aeruginosa & PA14 \\
\hline
\end{tabular}

\subsection{Drugs and Antibiotics}

IMD0354 (Tocris 2611), gentamicin, daptomycin, and vancomycin (Sigma Aldrich) stocks were dissolved to $10 \mathrm{mg} / \mathrm{mL}$ in DMSO. Ciprofloxacin (Sigma Aldrich) was dissolved to $10 \mathrm{mg} / \mathrm{mL}$ in $0.1 \mathrm{~N} \mathrm{HCl}$.

\subsection{Minimum Inhibitory Concentration Assay}

Minimum Inhibitory Concentration assays were carried out as described by the Clinical and Laboratory Standard Institute [53]. In brief, bacterial strains grown overnight in appropriate media for 20-23 h were diluted to $1 \times 10^{6} \mathrm{CFU} / \mathrm{mL}$ in Mueller-Hinton Broth (MHB, BD Difco, pH: $7.3 \pm 0.1$ ). In a 96-well plate $50 \mu \mathrm{L}$ of diluted culture was added to $50 \mu \mathrm{L}$ of serial two-fold diluted drug in MHB to a final concentration of $5 \times 10^{5} \mathrm{CFU} / \mathrm{mL}$. All assays were performed in triplicate. Experimental 
plates were incubated for $20-22 \mathrm{~h}$ at $37^{\circ} \mathrm{C}$. Optical density at $600 \mathrm{~nm}\left(\mathrm{OD}_{600}\right)$ was measured using a spectrophotometer (SpectraMax M2, Molecular Devices) as a measure of bacterial growth. MIC was defined as $\mathrm{OD}_{600} \leq 0.1$ after background subtraction.

\subsection{C. elegans Infection Assay for Compound Screening}

All compounds were screened as previously described in Kim et al. 2014 [19]. In brief, $g l p-4$ (bn2); sek-1 $(\mathrm{km} 4)$ worm embryos were synchronized by plating 2000 L1 worms on SK agar plates with HB101 bacteria as a food source at $15{ }^{\circ} \mathrm{C}$ for four days until they reached gravid adult stage. Eggs were harvested and hatched in $\mathrm{M} 9$ buffer at $15^{\circ} \mathrm{C}$ for $48 \mathrm{~h}$. L1 stage worms were then transferred onto SKHB101 plates and incubated at $25^{\circ} \mathrm{C}$ for $52 \mathrm{~h}$ to induce sterility. Sterile young adult stage worms were harvested using M9 buffer and sorted into black, clear-bottom, 384-well plates (Corning no. 3712) containing compounds at 15 worms/well using Copa Biosort Instrument. S. aureus MW2 bacteria was grown overnight in TSB at $37^{\circ} \mathrm{C}$ with agitation. A static culture was inoculated by seeding $100 \mu \mathrm{L}$ of an overnight culture in $10 \mathrm{~mL}$ of fresh TSB, sealed to produce anaerobic conditions, and incubated at $37^{\circ} \mathrm{C}$ overnight without agitation. We have found that MW2 grown anaerobically elicits a greater infection mortality rate in C. elegans. Furthermore, anaerobically grown MRSA MW2 cells express different virulence gene patterns [54]. Static MW2 was added to C. elegans-compound 384-well plates at a final concentration of $\mathrm{OD}_{600}$ 0.04. Final well composition consisted of $70 \% \mathrm{M} 9$ buffer, $19 \%$ Sheath solution (Union Biometrica Part no. 300-5101-000), 10\% TSB, and 1\% DMSO or compounds dissolved in DMSO. After a 5-day incubation at $25^{\circ} \mathrm{C}$ worms were washed using a multiplate washer and incubated overnight at $37^{\circ} \mathrm{C}$ with Sytox Orange dissolved in M9 at a final concentration of $0.7 \mu \mathrm{M}$. The following day, all plates were imaged using an Image Xpress Micro automated microscope (Molecular Devices), capturing both transmitted light and TRITC ( $535 \mathrm{~nm}$ excitation, $610 \mathrm{~nm}$ emission) fluorescent images using a $2 \times$ objective.

\subsection{C. elegans Dose-Dependent Toxicity Assay}

In a black, clear-bottom, 96-well plate (Corning, no. 3690) IMD0354 was serially diluted to a final volume of $50 \mu \mathrm{L}$ using M9. N2 worms were sterilized by growing to young adult stage fed on RNAi $c d c 25.1$ activated by $1 \mathrm{mM}$ of IPTG [55] for $48 \mathrm{~h}$ at $25^{\circ} \mathrm{C}$. $c d c 25.1$ is an integral part of germ cell mitosis. Mutations of $c d c 25.1$ inhibits germ line cell division producing C. elegans incapable of laying eggs [56]. Young adult worms were washed 3 times with $50 \mathrm{~mL}$ of M9 and diluted to an average of 21 worms $\pm 7 / 25 \mu \mathrm{L}$ using a multichannel pipette. An additional $25 \mu \mathrm{L}$ of heat killed OP50 were added to each well to a make a final volume of $100 \mu \mathrm{L}$ and $\mathrm{OD}_{600}$ of 0.5 . All assays were performed in duplicate. Experimental plates were incubated for $24 \mathrm{~h}$ at $25^{\circ} \mathrm{C}$. Worms were then washed using a 405 LS microplate washer (BioTek) and incubated with $0.7 \mu \mathrm{M}$ SYTOX Orange for an additional $24 \mathrm{~h}$ at $25^{\circ} \mathrm{C}$. Each plate was then imaged using an Xpress Micro automated microscope (Molecular Devices) capturing both transmitted light and TRITC ( $535 \mathrm{~nm}$ excitation, $610 \mathrm{~nm}$ emission) fluorescent images using a $2 X$ objective. Surviving worms were considered those with no TRITC signal relative to the control.

\subsection{Bacterial Time-Course Killing Assay}

Strain VRS1 [32], grown overnight in TSB medium for 20-23 h, was diluted 1:1000 $\left(1 \times 10^{6} \mathrm{CFU} / \mathrm{mL}\right)$ in MHB (BD Difco, pH 7.3 \pm 0.1) in a deep 96-well plate. $250 \mu \mathrm{L}$ of diluted culture was added to $250 \mu \mathrm{L}$ of serial two-fold diluted drug in MHB to a final concentration of $5 \times 10^{5} \mathrm{CFU} / \mathrm{mL}$. At time $0,1 \mathrm{~h}, 2 \mathrm{~h}$, $3 \mathrm{~h}, 4 \mathrm{~h}$, and $24 \mathrm{~h}, 50-\mu \mathrm{L}$ samples were removed, serially diluted by 10 -fold steps, and spot-plated on MHB agar (BD Difco) plates to enumerate the number $\mathrm{CFU} / \mathrm{mL}$. These experiments were conducted in triplicate. Experimental plates were incubated for $20-22 \mathrm{~h}$ at $37^{\circ} \mathrm{C}$. 


\subsection{Human Blood Hemolysis}

Hemolytic activity of IMD0354 on human erythrocytes was evaluated using a previously described method with modifications [57]. 10\% human erythrocytes were purchased from Rockland Immunochemicals (Limerick, PA, USA). The erythrocytes were diluted to $4 \%$ with phosphate buffered saline (PBS), and $50 \mu \mathrm{L}$ was added to $50 \mu \mathrm{L}$ of two-fold serial dilutions of compounds in PBS, $0.2 \%$ DMSO (negative control), or 1\% Triton-X 100 (positive control) in a 96-well plate. The plate was incubated at room temperature for $1 \mathrm{~h}$ and then centrifuged at $500 \times g$ for $5 \mathrm{~min}$. $50 \mu \mathrm{L}$ of the supernatant was transferred to a fresh 96-well plate and absorbance of supernatants was measured at $540 \mathrm{~nm}$. Percent hemolysis was calculated using the following equation: (A540nm of compound treated sample-A540nm of $0.1 \%$ DMSO treated sample)/(A540nm of $1 \%$ Triton X-100 treated sample-A540nm of $0.1 \%$ DMSO treated sample) $\times 100$. These experiments were conducted in triplicate.

\subsection{Antibiotic-Tolerant Cell Killing}

S. aureus VRS1 [32] antibiotic-tolerant cells were acquired by growing liquid cultures $>18 \mathrm{~h}$ to stationary-phase at $37^{\circ} \mathrm{C}$ in $25 \mathrm{~mL}$ of TSB [46]. Stationary-phase VRS1 cell tolerance to various antibiotics was previously proven by Kim et al. 2018 [46]. In brief, overnight cultures were washed three times with PBS (pH: 7.4) and diluted to a final concentration of $1.0 \times 10^{6} \mathrm{CFU} / \mathrm{mL} .500 \mu \mathrm{L}$ of washed cells were added to $500 \mu \mathrm{L}$ of indicated concentrations of drug in $2 \mathrm{~mL}$ deep-dish 96-well plates and incubated at $37^{\circ} \mathrm{C}$ with agitation for 1, 2, 3, and $4 \mathrm{~h}$. In order to wash any residual drug from sample time points, $400 \mu \mathrm{L}$ of sample was collected every hour and centrifuged at 15,000 rpm for 3 min and suspended with $400 \mu \mathrm{L}$ of fresh PBS. $100 \mu \mathrm{L}$ of washed samples were serially diluted and spot-plated on MHB agar plates to measure antibiotic-tolerant cell CFU $/ \mathrm{mL}$. These experiments were conducted in triplicate.

\subsection{SYTOX Green Membrane Permeability Assay}

These studies were conducted as previously described in Kim et al. 2018 [19]. In brief, black, clear-bottom, 96-well plates (Corning no. 3904, Corning, NY, USA) were filled with $50 \mu \mathrm{L}$ of PBS (pH: 7.4) containing $2 \times$ the indicated concentration of antibiotics. Stationary-phase VRS1 cells prepared as described in the antibiotic-tolerant cell killing assay were washed 3 times with equal volumes of PBS. Washed cells were then adjusted to $\mathrm{OD}_{600} 0.4\left(\sim 2 \times 10^{7} \mathrm{CFU} / \mathrm{mL}\right)$ with PBS. SYTOX Green (Molecular Probes, Waltham, MA, USA) was added to $10 \mathrm{~mL}$ of the diluted bacterial suspension to a final concentration of $5 \mu \mathrm{M}$ and incubated for $30 \mathrm{~min}$ at room temperature in the dark. $50 \mu \mathrm{L}$ of the bacteria/SYTOX Green mixture was added to each well of the 96-well plates containing antibiotics. Fluorescence was measured at room temperature using a spectrophotometer (SpectraMax M2, Molecular Devices, Sunnyvale, CA, USA), with excitation and emission wavelengths of $485 \mathrm{~nm}$ and $525 \mathrm{~nm}$, respectively. All experiments were conducted in triplicate.

\subsection{Biofilm Initial Cell Attachment Assay}

S. aureus strainVRS1 [32] was grown overnight $(>18 \mathrm{~h}$ ) in BHI (Sigma, pH: $7.4 \pm 0.2)$. Absorbance at $\mathrm{OD}_{600}$ was measured and adjusted to 0.2 in $\mathrm{BHI}+0.1 \%$ glucose medium. $100 \mu \mathrm{L}$ of bacteria was added to $2 \times$ drug concentrations being tested producing a final volume of $200 \mu \mathrm{L}, \mathrm{OD}_{600}$ of $0.1\left(\sim 8 \times 10^{7} \mathrm{CFU} / \mathrm{mL}\right)$ and $1 \times$ drug concentration. The plates were then incubated at $37^{\circ} \mathrm{C}$ for $1 \mathrm{~h}$. Media were then pipetted out and the wells were washed 3 times with PBS to remove any non-adherent planktonic cells. Biofilm initial cell attachment was measured as described in Biswajit et al. 2016 [58]. In brief, colorimetric quantification of the inhibition of biofilm initial cell attachment was done using XTT [2-3-bis(2-methyloxy-4-nitro-5- sulfophenyl)-2H-tertazolium-5-carboxanilide] assay kit following manufacture instructions with minor adjustments (Sigma-Aldrich, MO, USA). $180 \mu \mathrm{L}$ of fresh TSB and $20 \mu \mathrm{L}$ of XTT solution were added to each well and the plates were again incubated for $2 \mathrm{~h}$ at $37^{\circ} \mathrm{C}$. 
Absorbance at $450 \mathrm{~nm}$ was measured and each experimental well was normalized to a non-treatment control. Each biological replicate was done in quadruplicates. One replicate was done in octuplet.

\subsection{Biofilm Inhibition Assay}

S. aureus VRS1 [32] was grown overnight $(>18 \mathrm{~h})$ in $\mathrm{BHI}$ (Sigma, $\mathrm{pH}: 7.4 \pm 0.2)$. Absorbance at $\mathrm{OD}_{600}$ was measured and adjusted to 0.1 in $\mathrm{BHI}+0.1 \%$ glucose medium. $100 \mu \mathrm{L}$ of bacteria was added to $2 \times$ drug concentrations being tested producing a final volume of $200 \mu \mathrm{L}, \mathrm{OD}_{600}$ of 0.05 $\left(\sim 4 \times 10^{7} \mathrm{CFU} / \mathrm{mL}\right)$ and $1 \times$ drug concentration. The plates were then incubated at $37^{\circ} \mathrm{C}$ for $24 \mathrm{~h}$. Media were then pipetted out and the wells were washed 3 times with PBS to remove any non-adherent planktonic cells. Biofilm inhibition was measured using crystal violet (CV) [59]. In brief, plates were incubated with $1 \% \mathrm{CV}$ for $15 \mathrm{~min}$ at room temperature. Plates were then washed 3 times with PBS and dissolved with $200 \mu \mathrm{L}$ of $30 \%$ acetic acid. Absorbance at $550 \mathrm{~nm}$ was measured and each experimental well was normalized to a non-treatment control. Each biological replicate was done in octuplet.

\subsection{Mammalian Cancer Cell Viability Assay}

Two-fold concentration drug plates were prepared using Dulbecco's Modified Eagle's medium (DMEM) with 10\% FBS. HepG2 or HKC-8 cells were grown in DMEM 10\% FBS to confluency and seeded onto 96 -well drug plates at $1.0 \times 10^{6}$ cells $/ \mathrm{mL}$ and $0.4 \times 10^{6}$ cells $/ \mathrm{mL}$, respectively. Drug and cell plate were then incubated for $22 \mathrm{~h}$ at $37{ }^{\circ} \mathrm{C}$ and $5 \% \mathrm{CO}_{2}$. At $22 \mathrm{~h}, 10 \mu \mathrm{L}$ of WST-1 (Roche, Sigma) was added to each well, following manufacturer's directions, and incubated for an additional $2 \mathrm{~h}$. Plate absorbance was read at $450 \mathrm{~nm}$. Samples were normalized to a non-treatment control. All experiments were conducted in triplicate.

\section{Conclusions}

In conclusion, we report that, at low concentrations $(\leq 2 \mu \mathrm{g} / \mathrm{mL})$, IMD0354 can act both as a bactericidal and bacteriostatic against VISA, VRSA, and VRE strains, while, at high concentrations ( $\geq 8 \mu \mathrm{g} / \mathrm{mL}$ ), IMD0354 demonstrates bactericidal activity. IMD0354 does not show any hemolytic activity at concentrations up to $16 \mu \mathrm{g} / \mathrm{mL}$ and shows no toxicity to C. elegans up to $2 \mu \mathrm{g} / \mathrm{mL}$ and $90 \%$ survival at $>64 \mu / \mathrm{mL}$. Our data reveal that the antimicrobial mechanism of IMD0354 at high concentrations $\geq 4 \mu \mathrm{g} / \mathrm{mL}$ is membrane permeabilization. However, we are still unclear what the MOA is at low concentrations. Importantly, we find that IMD0354 is a more potent antimicrobial than anti-cancer agent. Moving forward, we believe that the further development of this compound is important. Nonetheless, further research to develop this multi-bioactive compound will require distinguishing the structural relationship between NF- $\mathrm{BB}$ inhibition, anti-cancer, and antimicrobial effects in order to overcome toxicity and cross-reaction side effects.

Supplementary Materials: The following are available online at http://www.mdpi.com/2079-6382/9/10/665/s1, Figure S1: IMD0354 does not kill VRS1 antibiotic-tolerant cells.

Author Contributions: Conceptualization, E.M. and W.K.; methodology, I.E.E. and A.W.; formal analysis, I.E.E.; investigation, I.E.E.; data curation, I.E.E.; writing—original draft preparation, I.E.E.; writing—review and editing, I.E.E., E.M. and W.K.; supervision, E.M. and W.K. All authors have read and agreed to the published version of the manuscript.

Funding: This research was funded by NIH grant P01 AI083214 to E.M. W.K. is supported by the National Research Foundation of Korea Grants funded by the Korea government (MSIT) (2020R1C1C1008842, 2018R1A5A2025286 and 2017M3A9E4077234). The authors have no other relevant affiliations or financial involvement with any organization or entity with a financial interest in, or financial conflict with, the subject matter or materials discussed in the manuscript, apart from those disclosed. No writing assistance was utilized in the production of this manuscript.

Conflicts of Interest: The authors declare no conflict of interest. 


\section{References}

1. David, M.Z.; Daum, R.S. Community-Associated Methicillin-Resistant Staphylococcus aureus: Epidemiology and Clinical Consequences of an Emerging Epidemic. Clin. Microbiol. Rev. 2010, 23, 616-687. [CrossRef] [PubMed]

2. Lowy, F.D. Staphylococcus aureus infections. N. Engl. J. Med. 1998, 339, 520-532. [CrossRef] [PubMed]

3. Lakhundi, S.; Zhang, K. Methicillin-Resistant Staphylococcus aureus: Molecular Characterization, Evolution, and Epidemiology. Clin. Microbiol. Rev. 2018, 31. [CrossRef]

4. Stogios, P.J.; Savchenko, A. Molecular mechanisms of vancomycin resistance. Protein Sci. 2020, $29,654-669$. [CrossRef] [PubMed]

5. Hiramatsu, K.; Aritaka, N.; Hanaki, H.; Kawasaki, S.; Hosoda, Y.; Hori, S.; Fukuchi, Y.; Kobayashi, I. Dissemination in Japanese hospitals of strains of Staphylococcus aureus heterogeneously resistant to vancomycin. Lancet 1997, 350, 1670-1673. [CrossRef]

6. Howe, R.A.; Bowker, K.E.; Walsh, T.R.; Feest, T.G.; MacGowan, A.P. Vancomycin-resistant Staphylococcus aureus. Lancet 1998, 351, 602. [CrossRef]

7. Hidayat, L.K.; Hsu, D.I.; Quist, R.; Shriner, K.A.; Wong-Beringer, A. High-dose vancomycin therapy for methicillin-resistant Staphylococcus aureus infections: Efficacy and toxicity. Arch. Intern. Med. 2138, 166, 2006-2144. [CrossRef]

8. Leclercq, R.; Derlot, E.; Duval, J.; Courvalin, P. Plasmid-mediated resistance to vancomycin and teicoplanin in Enterococcus faecium. N. Engl. J. Med. 1988, 319, 157-161. [CrossRef]

9. Uttley, A.H.; Collins, C.H.; Naidoo, J.; George, R.C. Vancomycin-resistant enterococci. Lancet 1988, 2, 57-58. [CrossRef]

10. Dougherty, T.J.; Pucci, M.J. Antibiotic Discovery and Development; Springer Science \& Business Media: Boston, MA, USA, 2011.

11. Munita, J.M.; Arias, C.A. Mechanisms of Antibiotic Resistance. Microbiol. Spectr. 2016, 4, 481-511. [CrossRef]

12. Arthur, M.; Molinas, C.; Courvalin, P. The VanS-VanR two-component regulatory system controls synthesis of depsipeptide peptidoglycan precursors in Enterococcus faecium BM4147. J. Bacteriol. 1992, 174, 2582-2591. [CrossRef]

13. Meziane-Cherif, D.; Saul, F.A.; Haouz, A.; Courvalin, P. Structural and functional characterization of VanG D-Ala:D-Ser ligase associated with vancomycin resistance in Enterococcus faecalis. J. Biol. Chem. 2012, 287, 37583-37592. [CrossRef] [PubMed]

14. Tattevin, P.; Arvieux, C.; Michelet, C. Alternative agents for the treatment of invasive infections due to methicillin-resistant Staphylococcus aureus strains with reduced susceptibility to vancomycin. Arch. Intern. Med. 2007, 167, 1206. [CrossRef] [PubMed]

15. Gomes, D.M.; Ward, K.E.; LaPlante, K.L. Clinical implications of vancomycin heteroresistant and intermediately susceptible Staphylococcus aureus. Pharmacotherapy 2015, 35, 424-432. [CrossRef] [PubMed]

16. Rybak, M.J.; Hershberger, E.; Moldovan, T.; Grucz, R.G. In vitro activities of daptomycin, vancomycin, linezolid, and quinupristin-dalfopristin against Staphylococci and Enterococci, including vancomycinintermediate and -resistant strains. Antimicrob. Agents Chemother. 2000, 44, 1062-1066. [CrossRef] [PubMed]

17. Chen, C.-J.; Huang, Y.-C.; Shie, S.-S. Evolution of Multi-Resistance to Vancomycin, Daptomycin, and Linezolid in Methicillin-Resistant Staphylococcus aureus Causing Persistent Bacteremia. Front. Microbiol. 2020, 11, 1414. [CrossRef]

18. Nannini, E.; Murray, B.E.; Arias, C.A. Resistance or decreased susceptibility to glycopeptides, daptomycin, and linezolid in methicillin-resistant Staphylococcus aureus. Curr. Opin. Pharmacol. 2010, 10, 516-521. [CrossRef]

19. Kim, W.; Zhu, W.; Hendricks, G.L.; Van Tyne, D.; Steele, A.D.; Keohane, C.E.; Fricke, N.; Conery, A.L.; Shen, S.; Pan, W.; et al. A new class of synthetic retinoid antibiotics effective against bacterial persisters. Nature 2018, 556, 103-107. [CrossRef]

20. Kim, S.M.; Escorbar, I.; Lee, K.; Fuchs, B.B.; Mylonakis, E.; Kim, W. Anti-MRSA agent discovery using Caenorhabditis elegans-based high-throughput screening. J. Microbiol. 2020, 58, 431-444. [CrossRef]

21. Kim, W.; Steele, A.D.; Zhu, W.; Csatary, E.E.; Fricke, N.; Dekarske, M.M.; Jayamani, E.; Pan, W.; Kwon, B.; Sinitsa, I.F.; et al. Discovery and Optimization of nTZDpa as an Antibiotic Effective against Bacterial Persisters. ACS Infect. Dis. 2018, 4, 1540-1545. [CrossRef] 
22. Kim, W.; Zou, G.; Hari, T.P.A.; Wilt, I.K.; Zhu, W.; Galle, N.; Faizi, H.A.; Hendricks, G.L.; Tori, K.; Pan, W.; et al. A selective membrane-targeting repurposed antibiotic with activity against persistent methicillin-resistant Staphylococcus aureus. Proc. Natl. Acad. Sci. USA 2019, 116, 16529-16534. [CrossRef] [PubMed]

23. Kim, W.; Zou, G.; Pan, W.; Fricke, N.; Faizi, H.A.; Kim, S.M.; Khader, R.; Li, S.; Lee, K.; Escorba, L.; et al. The Neutrally Charged Diarylurea Compound PQ401 Kills Antibiotic-Resistant and Antibiotic-Tolerant Staphylococcus aureus. mBio 2020, 11, 603. [CrossRef] [PubMed]

24. Onai, Y.; Suzuki, J.-I.; Kakuta, T.; Maejima, Y.; Haraguchi, G.; Fukasawa, H.; Muto, S.; Itai, A.; Isobe, M. Author NotesInhibition of IkappaB phosphorylation in cardiomyocytes attenuates myocardial ischemia/reperfusion injury. Cardiovasc. Res. 2004, 63, 51-59. [CrossRef] [PubMed]

25. Kim, S.; Ko, D.; Lee, Y.; Jang, S.; Lee, Y.; Lee, I.Y.; Kim, S. Anti-cancer activity of the novel 2-hydroxydiarylamide derivatives IMD-0354 and KRT1853 through suppression of cancer cell invasion, proliferation, and survival mediated by TMPRSS4. Sci. Rep. 2019, 9, 10003. [CrossRef]

26. Kinose, Y.; Sawada, K.; Makino, H.; Tomonori, O.; Tomoko, M.; Noriko, S.; Tomoyuki, F.; Eiichi, M.; Koji, N.; Ikuko, S.; et al. IKK $\beta$ Regulates VEGF Expression and Is a Potential Therapeutic Target for Ovarian Cancer as an Antiangiogenic Treatment. Mol. Cancer Ther. 2015, 14, 909-919. [CrossRef] [PubMed]

27. Gomez-Cabrero, A.; Wrasidlo, W.; Reisfeld, R.A. IMD-0354 targets breast cancer stem cells: A novel approach for an adjuvant to chemotherapy to prevent multidrug resistance in a murine model. PLOS ONE 2013, 8, e73607. [CrossRef]

28. Sugita, A.; Ogawa, H.; Azuma, M.; Muto, S.; Honjo, A.; Yanagawa, H.; Nishioka, Y.; Tani, K.; Itai, A.; Sone, S. Antiallergic and anti-inflammatory effects of a novel I kappaB kinase beta inhibitor, IMD-0354, in a mouse model of allergic inflammation. Int. Arch. Allergy Immunol. 2009, 148, 186-198. [CrossRef]

29. Barker, W.T.; Nemeth, A.M.; Brackett, S.M.; Basak, A.K.; Chandler, C.E.; Jania, L.A.; Zuercher, W.J.; Melander, R.J.; Koller, B.H.; Ernst, R.K.; et al. Repurposing Eukaryotic Kinase Inhibitors as Colistin Adjuvants in Gram-Negative Bacteria. ACS Infect. Dis. 2019, 5, 1764-1771. [CrossRef]

30. Rice, L.B. Federal funding for the study of antimicrobial resistance in nosocomial pathogens: No ESKAPE. J. Infect. Dis. 2008, 197, 1079-1081. [CrossRef]

31. Pendleton, J.N.; Gorman, S.P.; Gilmore, B.F. Clinical relevance of the ESKAPE pathogens. Expert Rev. Anti-Infect. Ther. 2013, 11, 297-308. [CrossRef]

32. Weigel, L.M.; Clewell, D.B.; Gill, S.R.; Clark, N.C.; McDougal, L.K.; Flannagan, S.E.; Kolonay, J.F.; Shetty, J.; Killgore, G.E.; Tenover, F.C. Genetic analysis of a high-level vancomycin-resistant isolate of Staphylococcus aureus. Science 2003, 302, 1569-1571. [CrossRef] [PubMed]

33. Centers for Disease Control and Prevention. CDC E FDA Antibiotic Resistance (AR) Isolate Bank; CDC: Atlanta, GA, USA, 2019.

34. Gupta, V.; Singla, N.; Behl, P.; Sahoo, T.; Chander, J. Antimicrobial susceptibility pattern of vancomycin resistant enterococci to newer antimicrobial agents. Indian J. Med. Res. 2015, 141, 483-486. [CrossRef] [PubMed]

35. Carias, L.L.; Rudin, S.D.; Donskey, C.J.; Rice, L.B. Genetic linkage and cotransfer of a novel, vanB-containing transposon Tn5382) and a low-affinity penicillin-binding protein 5 gene in a clinical vancomycin-resistant Enterococcus faecium isolate. J. Bacteriol. 1998, 180, 4426-4434. [CrossRef] [PubMed]

36. Williamson, R.; Al-Obeid, S.; Shlaes, J.H.; Goldstein, F.W.; Shlaes, D.M. Inducible resistance to vancomycin in Enterococcus faecium D366. J. Infect. Dis. 1989, 159, 1095-1104. [CrossRef]

37. Thorisdottir, A.S.; Carias, L.L.; Marshall, S.H.; Green, M.; Zervos, M.J.; Giorgio, C.; Mermel, L.A.; Boyce, J.M.; Medeiros, A.A.; Fraimowet, H.; et al. IS6770, an enterococcal insertion-like sequence useful for determining the clonal relationship of clinical enterococcal isolates. J. Infect. Dis. 1994, 70, 1539-1548. [CrossRef]

38. Evers, S.; Sahm, D.F.; Courvalin, P. The vanB gene of vancomycin-resistant Enterococcus faecalis V583 is structurally related to genes encoding D-Ala:D-Ala ligases and glycopeptide-resistance proteins VanA and VanC. Gene 1993, 24, 143-144. [CrossRef]

39. Racusen, L.C.; Monteil, C.; Sgrignoli, A.; Lucskay, M.; Marouillat, S.; Rhim, J.G.; Morin, J.P. Cell lines with extended in vitro growth potential from human renal proximal tubule: Characterization, response to inducers, and comparison with established cell lines. J. Lab. Clin. Med. 1997, 129, 318-329. [CrossRef]

40. Kim, W.; Conery, A.L.; Rajamuthiah, R.; Fuchs, B.B.; Ausubel, F.M.; Mylonakis, E. Identification of an antimicrobial agent effective against methicillin-resistant Staphylococcus aureus persisters using a fluorescence-based screening strategy. PLoS ONE 2015, 10, e0127640. [CrossRef] 
41. Percival, S.L.; Suleman, L.; Vuotto, C.; Donelli, G. Healthcare-associated infections, medical devices and biofilms: Risk, tolerance and control. J. Med. Microbiol. 2015, 64 Pt 4, 64323-64334. [CrossRef]

42. Moormeier, D.E.; Bayles, K.W. Staphylococcus aureus biofilm: A complex developmental organism. Mol. Microbiol. 2017, 104, 365-376. [CrossRef]

43. Chung, P.Y.; Toh, Y.S. Anti-biofilm agents: Recent breakthrough against multi-drug resistant Staphylococcus aureus. Pathog. Dis. 2014, 70, 231-239. [CrossRef] [PubMed]

44. Bjarnsholt, T.; Ciofu, O.; Molin, S.; Givskov, M.; Høiby, N. Applying insights from biofilm biology to drug development-Can a new approach be developed? Nat. Rev. Drug Discov. 2013, 12, 791-808. [CrossRef] [PubMed]

45. Hurdle, J.G.; O’Neill, A.J.; Chopra, I.; Lee, R.E. Targeting bacterial membrane function: An underexploited mechanism for treating persistent infections. Nat. Rev. Microbiol. 2010, 9, 62-75. [CrossRef] [PubMed]

46. Kim, W.; Fricke, N.; Conery, A.L.; Fuchs, B.B.; Rajamuthiah, R.; Jayamani, E.; Vlahovska, P.M.; Ausubel, F.M.; Mylonakis, E. NH125 kills methicillin-resistant Staphylococcus aureus persisters by lipid bilayer disruption. Future Med. Chem. 2016, 8, 257-269. [CrossRef]

47. Raetz, C.R.H.; Whitfield, C. Lipopolysaccharide endotoxins. Annu. Rev. Biochem. 2002, 71, 635-700. [CrossRef]

48. Tanaka, A.; Konno, M.; Muto, S.; Kambe, N.; Morii, E.; Nakahata, T.; Itai, A.; Matsuda, H. A novel NF-kappaB inhibitor, IMD-0354, suppresses neoplastic proliferation of human mast cells with constitutively activated c-kit receptors. Blood 2005, 105, 2324-2331. [CrossRef]

49. Kwan, B.W.; Chowdhury, N.; Wood, T.K. Combatting bacterial infections by killing persister cells with mitomycin C. Environ. Microbiol. 2015, 17, 4406-4414. [CrossRef]

50. Chowdhury, N.; Wood, T.L.; Martinez-Vazquez, M.; García-Contreras, R.; Wood, T.K. DNA-crosslinker cisplatin eradicates bacterial persister cells. Biotechnol. Bioeng. 2016, 113, 1984-1992. [CrossRef]

51. Yang, E.B.; Tang, W.Y.; Zhang, K.; Cheng, L.Y.; Mack, P.O. Norcantharidin inhibits growth of human HepG2 cell-transplanted tumor in nude mice and prolongs host survival. Cancer Lett. 1997, 117, 93-98. [CrossRef]

52. Li, Y.; Wang, Z.; Ma, X.; Shao, B.; Gao, X.; Zhang, B.; Xu, G.; Wei, Y. Low-dose cisplatin administration to septic mice improves bacterial clearance and programs peritoneal macrophage polarization to M1 phenotype. Pathog. Dis. 2014, 72, 111-123. [CrossRef]

53. CLSI. M07-A9: Methods for Dilution Antimicrobial Susceptibility Tests for Bacteria That Grow Aerobically, 9th ed.; Approved Standard; CLSI: Sydney NSW, Australia, 2012; pp. 1-88.

54. Fuchs, S.; Pané-Farré, J.; Kohler, C.; Hecker, M.; Engelmann, S. Anaerobic gene expression in Staphylococcus aureus. J. Bacteriol. 2007, 189, 4275-4289. [CrossRef] [PubMed]

55. Yuen, G.J.; Ausubel, F.M. Both live and dead Enterococci activate Caenorhabditis elegans host defense via immune and stress pathways. Virulence 2018, 9, 683-699. [CrossRef] [PubMed]

56. Kim, J.; Lee, A.-R.; Kawasaki, I.; Strome, S.; Shim, Y.-H. A mutation of $c d c-25.1$ causes defects in germ cells but not in somatic tissues in C. elegans. Mol. Cells 2009, 28, 43-48. [CrossRef] [PubMed]

57. Rajamuthiah, R.; Jayamani, E.; Conery, A.L.; Fuchs, B.B.; Kim, W.; Johnston, T.; Vilcinskas, A.; Ausubel, F.M.; Mylonakis, E. A Defensin from the Model Beetle Tribolium castaneum Acts Synergistically with Telavancin and Daptomycin against Multidrug Resistant Staphylococcus aureus. PLoS ONE 2015, 10, e0128576. [CrossRef]

58. Mishra, B.; Golla, R.M.; Lau, K.; Lushnikova, T.; Wang, G. Anti-Staphylococcal Biofilm Effects of Human Cathelicidin Peptides. ACS Med. Chem. Lett. 2016, 7, 117-121. [CrossRef]

59. O'Toole, G.A. Microtiter dish biofilm formation assay. J. Vis. Exp. 2011, 47, e2437. [CrossRef]

(C) 2020 by the authors. Licensee MDPI, Basel, Switzerland. This article is an open access article distributed under the terms and conditions of the Creative Commons Attribution (CC BY) license (http://creativecommons.org/licenses/by/4.0/). 